\title{
Perbandingan Hasil Belajar Fisika Antara Model Pembelajaran Problem Based Learning dengan Discovery Learning pada Siswa Kelas VIII SMP Negeri 12 Sigi
}

\author{
Kiki Riski Mutia Sari, Fihrin, dan Amiruddin Hatibe. \\ e-mail: hinatakiki5@gmail.com \\ Program Studi Pendidikan Fisika FKIP Universitas Tadulako \\ Jl. Soekarno Hatta Km. 9 Kampus Bumi Tadulako Tondo Palu - Sulawesi Tengah
}

\begin{abstract}
Penelitian ini dilakukan dengan tujuan menguji signifikansi perbedaan hasil belajar fisika antara kelompok siswa yang diberi pembelajaran dengan model pembelajaran problem based learning dengan kelompok siswa yang diajar dengan model pembelajaran discovery learning kelas VII SMP Negeri 12 Sigi. Jenis penelitian yang digunakan adalah eksperimen kuasi dengan desain "Non ekivalen pretest-posttest design". Sampel dipilih dengan menggunakan teknik purposive sampling. Instrumen yang digunakan berupa tes hasil belajar dalam bentuk pilihan ganda. Berdasarkan data hasil belajar fisika pada materi tekanan yang diperoleh, menunjukkan bahwa nilai rata-rata untuk kelas eksperimen A yaitu 20,38 dan standar deviasi sebesar 3,46, dan nilai rata-rata hasil belajar siswa untuk kelas eksperimen B yaitu 16,92 dan standar deviasi sebesar 4,12. Hasil uji t dua pihak dengan $\mathrm{dk}=50$ dan taraf signifikansi $\alpha=0,05$ diperoleh nilai thitung 3,65 dan nilai ini lebih besar dari $t_{\text {tabel }}(2,01)$. Nilai $t_{\text {hitung }}$ berada di luar daerah penerimaan $H_{0}$, dengan demikian $\mathrm{H}_{0}$ ditolak dan $\mathrm{H}_{1}$ diterima, sehingga dapat disimpulkan bahwa terdapat perbedaan yang signifikan pada hasil belajar fisika antara siswa yang diberi pembelajaran dengan model pembelajaran problem based learning dengan siswa yang diajar dengan model pembelajaran discovery learning.
\end{abstract}

Kata Kunci: Problem Based Learning, Discovery Learning, Hasil Belajar.

\section{PENDAHULUAN}

Belajar merupakan proses pertambahan ilmu pengetahuan yang dialami oleh seseorang atau suatu individu dengan melakukan interaksi terhadap segala sesuatu yang berada disekitarnya baik dalam proses melihat, merasakan, memahami, mengamati, dan mengalami beberapa hal [6] Belajar yang merupakan pertambahan ilmu pengetahuan itu sendiri bukan hanya terjadi di dalam ruangan kelas dalam bentuk penjelasan langsung oleh guru, melainkan dapat diperoleh dengan menggali sendiri suatu permasalahan hingga menemukan jalan keluarnya baik dalam bentuk diskusi, maupun mencari sendiri jawaban jawaban dari suatu permasalahan tersebut.

Dalam proses pembelajaran secara umum hal yang terjadi di dalam ruang kelas melibatkan dua pihak yaitu guru sebagai penyampai informasi yang dibutuhkan oleh siswa dan siswa sebagai penerima informasi. Dalam tahap ini siswa hanya cukup duduk, diam dan mendengarkan serta memperhatikan beberapa penjelasan yang telah diberikan oleh guru atau pengajar.

Dewasa ini sering dengan berkembangnya model - model pembelajaran terdapat beberapa model yang telah mngedepankan keaktifan siswa. Dalam hal ini, siswa dituntut lebih aktif dan lebih produktif karena ini merupakan kesempatan bagi siswa untuk menemukan gagasan dan ide - ide mereka dalam proses pembelajaran di kelas. Sedangkan peran guru dalam hal ini sebagai motivator, fasilitator, inspirator dan mediator juga bertindak sebagai pengarah untuk lancarnya kelangsungan proses pembelajaran.

Model pembelajaran yang hanya bertumpu/berpusat pada keaktifan guru tanpa memperhatikan keaktifan siswa akan membuat siswa merasa pasif. Selain itu juga, model pembelajaran yang seperti itu akan mengakibatkan siswa enggan untuk berpikir aktif, ini sama halnya dengan menghambat bahkan akan mematikan tumbuh kembang kreatifitasnya. Sehingga sangat sukar untuk menemukan ide - ide dan gagasan yang mungkin akan menjadi suatu karya besar dari 
pemikiran siswa dalam menyelesaikan setiap masalah yang diberikan oleh guru terkait dengan materi yang diajarkan.

Mengingat model pembelajaran yang hanya bertumpu pada satu pihak (guru) tersebut diatas, maka sangat diperlukan kreatifitas guru dalam mengolah ruang kelas dengan menggunakan model pembelajaran yang cocok untuk mengaktifkan kembali ide dan gagasan siswa.

Beberapa model pembelajaran yang dianggap mampu untuk menumbuhkan ide dan gagasan dalam kreativitas siswa adalah model pembelajaran Problem Based Learning dan Discovery Learning. Yang kedua model tersebut berpusat pada kreativitas siswa.

Berdasarkan hasil penelitian yang dilakukan [16] bahwa model pembelajaran Problem Based Learning sangat efektif dan memberi dampak positif terhadap penyelenggaraan proses pembelajaran. Model pembelajarab ini, memiliki pengaruh penting terhadap hasil belajar siswa dengan poin utamanya terletak pada tahapan - tahapannya seperti mendefinisikan dan menganalisis masalah, menyimpulkan alternatif pemecahan masalah, serta menguji hasil pemecahan masalah.

Sama halnya dengan Problem Based Learning, di beberapa jurnal lainnya Discovery Learning juga baik digunakan dalam proses pembelajaran. Model pembelajaran Discovery Learning adalah cara penyajian pelajaran yang banyak melibatkan siswa dalam proses - proses mental ( mengamati, mencerna, mengerti, menggolong - golongkan dan sebagainya) dalam rangka penemuannya.

Berdasarkan hasil observasi di sekolah SMP Negeri 12 Sigi, menunjukkan bahwa penyampaian materi dalam pembelajaran fisika masih berpusat kepada guru sehingga masih banyak siswa yang asyik sendiri dengan kegiatan yang siswa sukai dan cepat merasa bosan serta kadang menagntuk mendengarkan guru menyampaikan materi. Hal ini membuat siswa tidak benar - benar fokus dan memahami konsep fisika sehingga berdampak buruk pada hasil belajar siswa di SMP Negeri 12 Sigi.

Berdasarkan uraian tersebut, masalah yang terjadi saat ini adalah meningkatkan hasil belajar siswa maka dari itu perlu di lakukan penelitian yang berjudul " Perbandingan Hasil Belajar Fisika Antara Model Pembelajaran Problem Based Learning dengan Discovery Learning Pada Siswa Kelas VIII SMP Negeri 12 Sigi

\section{METODE PENELITIAN}

Penelitian yang digunakan adalah jenis penelitian dengan rancangan eksperimen kuasi (quasi-experimental design)

Desain penelitian yang digunakan yaitu the equivalent pretest-posttest design. [15] Desain penelitian yang digunakan dapat dilukiskan seperti pada Tabel 1

Tabel 1 Rancangan Prates-Pascates yang Equivalent
\begin{tabular}{|c|c|c|c|}
\hline Kelompok & Prates & Perlakuan & Pascates \\
\hline Eksperimen A & $\mathrm{O}_{1}$ & $\mathrm{X}_{1}$ & $\mathrm{O}_{2}$ \\
\hline Eksperimen B & $\mathrm{O}_{1}$ & $\mathrm{X}_{2}$ & $\mathrm{O}_{2}$ \\
\hline
\end{tabular}

Keterangan:

$\mathrm{X}_{1} \quad$ : Model pembelajaran Problem Based Learmimg

$\mathrm{X}_{2} \quad$ : Model pembelajaran Discovery Learning

$\mathrm{O}_{1} \quad$ : Tes awal

$\mathrm{O}_{2} \quad$ : Tes akhir

$\mathrm{O}_{1}=\mathrm{O}_{2}$

Penelitian dilakukan di SMP Negeri 12 Sigi. Populasi dalam penelitian ini adalah seluruh siswa kelas VIII SMP Negeri 12 Sigi tahun pelajaran 2015/2016 yang terdiri dari 4 kelas. Sampel dalam penelitian ini adalah kelas VIII C berjumlah 26 siswa dan VIII D yang berjumlah 26 siswa. Teknik pengumpulan sampel yang digunakan adalah purposive sampling, yaitu teknik penentuan sampel dengan pertimbangan tertentu.

Instrumen yang digunakan dalam penelitian ini adalah tes pilihan ganda untuk melihat hasil belajar siswa pada mata pelajaran fisika tentang tekanan yang telah divalidasi oleh validator ahli. Analisis data dilakukan dengan menganalisis instrumen terlebih dahulu menggunakan uji validitas item dan reliabilitas tes yang kemudian dengan menganalisis data hasil penelitian menggunakan uji normalitas, uji homogenitas, uji hipotesis

\section{HASIL DAN PEMBAHASAN}

\section{- Hasil Penelitian}

Berdasarkan hasil diskusi dari peneliti dan guru mata pelajaran fisika di SMP Negeri 12 Sigi, soal yang dibuat dalam bentuk pilihan ganda sebanyak 50 item soal. Setelah dibuat soal tersebut dikoreksi oleh dosen pembimbing untuk disesuaikan dengan tujuan pembelajaran yang ingin dicapai. Soal - soal tersebut kemudian diuji cobakan pada siswa SMP Negeri 12 Sigi Kelas IX yang sebelumnya telah menerima materi tekanan dan dianggap 
p-ISSN 2338-3240, e-ISSN 2580-5924

mempunyai kemampuan yang sama dengan siswa yang akan diteliti.

Berdasarkan hasil uji coba, selanjutnya dilakukan analisis berdasarkan validitas item, tingkat kesukaran, dan daya pembeda. Pada validitas item, soal yang dianggap valid memiliki harga $r \geq 0,25$ yaitu soal - soal nomor $1,4,5,8,9,10,11,13,14,17,18,19,20,21$, $22,23,24,25,26,28,31,36,37,39,44,45$, $46,47,49,50$.

Hasil analisis indeks kesukaran atau tingkat kesukaran soal - soal yang dapat diterima dengan indeks kesukaran berada pada rentang $0,31-0,70$ yaitu soal - soal nomor 1 , $2,4,5,6,8,11,13,14,15,17,21,22,23,24$, $25,26,27,28,29,32,33,36,38,39,41,42$, 46, 49 dan 50.

Selanjutnya untuk hasil analisis daya pembeda. Soal - soal yang mempunyai daya pembeda butir soal yang dapat di terima yaitu berada pada kategori kurang baik ( cukup) sampai baik sekali atau yang berada pada rentang $0,20-0,40$ yaitu soal dengan nomor 1 , $4,5,8,9,10,11,13,14,17,18,19,20,21$, $23,24,25,26,27,28,29,31,33,35,36,37$, $39,44,46,49$ dan 50 .

Setelah dilakukan analisis berdasarkan validitas item, tingkat kesukaran, dan daya pembeda maka selanjutnya dilakukan analisis berdasarkan realibilitas tes. Suatu tes dikatakan reliebel jika terdapat pada batasan $0,40, r_{11} \leq$ 1,00 dan nilai realibilitas tes $\left(r_{11}\right)$ yang diperoleh dari hasil penelitian ini sebesar 0,74. Hal ini menunjukkan bahwa nilai realibilitas tes hasil perhitungan lebih besar dibandingkan nilai realibilitas tes yang ditemukan. Berdasarkan hasil tes tersebut diketahui bahwa tes hasil belajar pada materi tekanan yang disusun dapat memberikan hasil yang tepat, atau mempunyai taraf kepercayaan yang tinggi.

Berdasarkan hasil tersebut, dari 50 item soal yang diuji cobakan pada siswa kelas IX, soal yang valid sebanyak 26 item soal, yaitu soal nomor $1,4,5,8,9,10,11,13,14,17,18$, $20,21,23,24,25,27,28,31,36,37,39,44$, 46,49 dan 50 . Sedangkan 24 item soal lainnya dinyatakan tidak valid yaitu soal nomor $2,3,6$, $7,12,15,16,19,22,26,29,30,32,34,35$, $38,40,41,42,43,45,47$ dan 48. Hasil penentuan kriteria penerimaan butir tes hasil

Tabel1 . Deskripsi Skor Tes Hasil Belajar Fisika Kelas

\begin{tabular}{|l|c|c|}
\multicolumn{1}{|c}{ VIII D dan Kelas VIII C (Pretest) } \\
\hline Jumlah Siswa & $\begin{array}{c}\text { Kelas VIII D } \\
\text { (Eksperimen A) }\end{array}$ & $\begin{array}{c}\text { Kelas VIII C } \\
\text { (Eksperimen B) }\end{array}$ \\
\hline Skor Minimum & 26 & 26 \\
\hline Skor Maksimum & 5 & 4 \\
\hline
\end{tabular}

\begin{tabular}{|l|c|c|}
\hline Skor Ideal & 26 & 26 \\
\hline Skor Total & 229 & 232 \\
\hline Skor Rata-rata & 8,81 & 8,922 \\
\hline Standar Deviasi & 2,43 & 2,80 \\
\hline
\end{tabular}

Hasil perhitungan analisis uji normalitas

Pretest dapat dilihat pada Tabel 3.

Tabel 2. Hasil Uji Normalitas Pretest Kelas Eksperimen A

\begin{tabular}{|c|c|c|c|}
\hline dan Kelas Eksperimen B \\
\hline Kelas & $\begin{array}{l}\text { Nilai } \\
X^{2} \text { Hitung }\end{array}$ & $\begin{array}{c}\text { Nilai } \\
X^{2} \text { tabel }(\alpha=0,05)\end{array}$ & Keputusan \\
\hline $\begin{array}{c}\text { Kelas } \\
\text { Eksperimen A }\end{array}$ & 2,20 & & $\begin{array}{c}\text { Terdistribusi } \\
\text { normal }\end{array}$ \\
\cline { 1 - 1 } $\begin{array}{c}\text { Kelas } \\
\text { Eksperimen } \\
\text { B }\end{array}$ & 3,84 & 7,81 & $\begin{array}{c}\text { Terdistribusi } \\
\text { normal }\end{array}$ \\
\hline
\end{tabular}

Berdasarkan hasil uji normaalitas diperoleh nilai $\mathrm{X}^{2}$ hitung $<\mathrm{X}^{2}$ tabel atau $\mathrm{X}^{2}$ hitung untuk kelas eksperimen dan kelas kontrol lebih keci dibandingkan nilai $\mathrm{X}^{2}$ tabel. Dimana untuk kelas eksperimen $2,20<7,81$ dan untuk kelas kontrol $3,84<7,81$. Sesuai kriteria pengambilan keputusan, maka data dari kelass eksperimen maupun kelas kontrol keduanya berasal dari populasi yang terdistribusi normal.

Hasil perhitungan analisis uji homogenitas Pretest dapat dilihat pada Tabel 3

Tabel 3. Hasil Uji Homogenitas Kelas Eksperimen A dan Kelas eksperimen B

\begin{tabular}{|c|c|c|c|c|}
\hline Kelas & $\begin{array}{c}\text { Nilai } \\
\text { Varians }\end{array}$ & $\begin{array}{c}\text { Nilai } \\
\text { F }_{\text {hitung }}\end{array}$ & $\begin{array}{c}\text { Nilai } \\
\mathbf{F}_{\text {tabel }} \\
\mathbf{F a} \\
(\mathbf{v 1 , v 2 )}\end{array}$ & Keputusan \\
\hline $\begin{array}{c}\text { Eksperimen } \\
\text { A }\end{array}$ & 6,38 & 0,72 & 1,93 & $\begin{array}{c}\text { Kedua data } \\
\text { homogen }\end{array}$ \\
\cline { 1 - 2 } $\begin{array}{c}\text { Eksperimen } \\
\text { B }\end{array}$ & $\mathbf{8 , 8 2}$ & & & \\
\hline
\end{tabular}

Berdasarkan hasil uji homogenitas, diketahui nilai $F_{\text {hitung }}$ lebih kecil dibandingkan nilai $F_{\text {tabel }}$. Dengan kata lain $F_{\text {hitung }}<F_{\text {tabel, }}$ secara matematis dapat dituliskan 0,72 < 1.93. Berdasarkan kriteria pengambilan keputusan, diketahui data tersebut memiliki varians yang sama atau homogen. Artinya, tidak terdapat perbedaan varians antara kelas eksperimen $A$ maupun kelas eksperimen $B$

Hasil perhitungan analisis uji beda dua rata-rata (dua pihak) Pretes dapat dilihat pada Tabel 5. 
Tabel 4. Uji Beda Rata-rata (Dua Pihak) Pretest Kelas Eksperimen A dan Kelas eksperimen B

\begin{tabular}{|c|c|c|c|c|}
\hline Kelas & $\begin{array}{c}\text { Nilai } \\
\text { Rata - } \\
\text { rata X }\end{array}$ & $\mathbf{t}_{\text {hitung }}$ & $\mathbf{t}_{\text {tabel }}$ & Keputusan \\
\hline $\begin{array}{c}\text { Eksperimen } \\
\text { A }\end{array}$ & 8,81 & $-0,14$ & 2,01 & $\mathrm{H}_{0}$ diterima \\
\cline { 1 - 2 } $\begin{array}{c}\text { Eksperimen } \\
\text { B }\end{array}$ & 8,92 & & & \\
\hline
\end{tabular}

Berdasarkan data, diketahui thitung $\geq$ ttabel atau $-0,14 \geq 2,01$. Hal ini berarti, nilai thitung berada pada daerah penerimaan $\mathrm{H}_{0}$. Dengan demikian $\mathrm{H}_{1}$ ditolak dan $\mathrm{H}_{0}$ diterima, dan dapat disimpulkan bahwa tidak ada terdapat perbedaan hasil belajar fisika antara kelompok kelas VIII d ( yang dijadikan kelas eksperimen A ) dan kelas VIIIc ( yang dijadikan sebagai kelas eksperimen B).

Tabel 5. Deskripsi Skor Tes Hasil Belajar Fisika Kelas VIII D dan VIII C

\begin{tabular}{|c|c|c|}
\hline Deskripsi & $\begin{array}{c}\text { Kelas } \\
\text { Eksperimen }\end{array}$ & Kelas Kontrol \\
\hline Jumlah Siswa & 26 & 26 \\
\hline Skor Minimum & 14 & 8 \\
\hline Skor Maksimum & 25 & 24 \\
\hline Skor Rata - rata & 20,38 & 16,92 \\
\hline Standar Deviasi & 3,46 & 3,98 \\
\hline
\end{tabular}

Hasil perhitungan analisis uji hipotesis Posttest dapat dilihat pada Tabel6.

Tabel 6. Uji Hipotesis Posttest Kelas Eksperimen A dan eksperimen B

\begin{tabular}{|c|c|c|c|c|}
\hline Kelas & $\begin{array}{c}\text { Nilai } \\
\text { Rata }- \\
\text { rata } \overline{\mathbf{X}}\end{array}$ & $\mathbf{t}_{\text {hitung }}$ & $\mathbf{t}_{\text {tabel }}$ & Keputusan \\
\hline $\begin{array}{c}\text { Eksperimen } \\
\text { A }\end{array}$ & 20,38 & 3,65 & 2,01 & $\mathrm{H}_{0}$ ditolak \\
\hline $\begin{array}{c}\text { Eksperimen } \\
\text { B }\end{array}$ & 16,92 & & \\
\hline
\end{tabular}

Berdasarkan data tabel 4.7 diketahui $t_{\text {thitung }} \geq$ tabel atau $3,65 \geq 2,01$. Hal ini berarti, nilai thitung berada diluar pada daerah penerimaan $\mathrm{H}_{0}$. Dengan demikian $\mathrm{H}_{0}$ ditolak dan $\mathrm{H}_{1}$ diterima, dan dapat disimpulkan bahwa terdapat perbedaan hasil belajar fisika antara kelompok siswa yang mengikuti model pembelajaran Problem Based Learning dengan model Discovery Learning.

\section{- Pembahasan}

Penelitian ini bertujuan untuk mengetahui apakah terdapat perbedaan hasil belajar fisika antara kelompok siswa yang mengikuti model pembelajaran Problem Based Learning dengan model Discovery Learning. Pada penelitian ini, kegiatan pembelajaran dilakukan sebanyak 5 kali pertemuan terdiri dari 3 kali tatap muka di kelas dan 2 kali pertemuan untuk preetest dan posstest dikedua kelas baik kelas ehsperimen $A$ maupun kelas eksperimen $B$.

Sebelum menerapkan model pembelajaran baik di kelas eksperimen $A$ maupun kelas eksperimen $B$, kedua kelas terlebih dahulu diberikan pretest. Tes awal ( pretest) digunakan untuk mengetahui bahwa kedua data berasal dari varians yang sama ( homogen ) atau memiliki kemampuan yang sama. Sedangkan tes akhir (posstest) diberikan untuk mengetahui kemampuan akhir siswa di kedua kelas dan sebagai data analisis penelitian selanjutnya digunakan sebagai pembanding untuk melihat apakah terdapat perbedaan hasil belajar antara kedua kelas tersebut terkait materi tekanan. Dalam pelaksanaan penelitian, kelas eksperimen A menggunakan model pembelajaran Problem Based Learning dan kelas eksperimen B menggunakan model pembelajaran Discovery Learning.

Berdasarkan penelitian yang dilakukan menggunakan model pembelajaran Problem Based Learning untuk kelas eksperimen A dan model pembelajaran Discovery Learning untuk kelas eksperimen $B$, kemampuan awal siswa dari pemberian tes awal (pretest) diperoleh skor rata - rata dari masing - masing kelas 8,81 untuk kelas eksperimen A dan 8,92 untuk kelas eksperimen B. Untuk tes akhir ( posttest) besar pencapaian skor rata - rata pada kelas eksperimen A yaitu sebesar 20,38 sedangkan pada kelas eksperimen B yaitu 16,92. Hasil ini menunjukkan adanya perbedaan skor antara dua kelas, dimana terlihat skor untuk kelas eksperimen A lebih tinggi dibandingkan kelas eksperimen B. Berdasarkan data tersebut, kemudian dilakukan analisis terhadap analisis terhadap normalitas serta homogenitas varians. Hasilnya baik data pretest maupun posttest, keduanya berdistribusi normal dan memiliki varians yang homogen.

Berdasarkan analisis kusntitatif data posttest, diketahui nilai rata - rata kelas eksperimen A lebih besar dibandingkan dengan nilai rata - rata kelas eksperimen B. Perbedaan antara rerata skor posttest kelas eksperimen $A$ dan kelas eksperimen B menunjukkan adanya perbedaan model pembelajaran yang diterapkan pada kedua kelas tersebut. Perbedaan yang signifikan terjadi pada kelas eksperimen A. Dimana kelas eksperimen A menggunakan model pembelajaran Problem Based Learning pada pembelajarannya sedangkan kelas eksperimen B menggunakan model pembelajaran Discovery Learning. 
Setelah dilakukan uji normalitas dan homogenitas varians, selanjutnya dilakukan uji hipotesis dengan menggunakan $u \mathrm{ji}$ - $\mathrm{t}$ dua pihak berdasarkan hasil skor pretest dan posttest.

Berdasarkan hasil skor posttest, dimana pada masing - masing kelas telah diberikan perlakuan, di peroleh nilai thitung $=3,65$ dan nilai $t_{\text {tabel }}=2,01$. Dengan menggunakan kriteria penerimaan $\mathrm{H}_{0}$ dimana $-\mathrm{t}(1-0,5 \mathrm{a})<\mathrm{t}<\mathrm{t}(1-0,5$ a ) diketahui hipotesis $\mathrm{H}_{0}$ tidak terpenuhi atau ditolak dan hipotesis satu $\left(\mathrm{H}_{1}\right)$ diterima. Artinya terdapat perbedaan hasil belajar antara kelas yang mendapatkan pembelajaran menggunakan model pembelajaran Problem Based Learning dengan kelas yang mendapatkan pembelajaran menggunakan model Discovery Learning.

Diperolehnya hasil tersebut dimungkinkan karena dalam pembelajaran menggunakan model Problem Based Learning, siswa berperan aktif dalam proses pembelajaran dan berusaha mencari tahu, saling berinteraksi dengan teman maupun guru, saling bertukar pikiran, sehingga mampu menemukan sendiri konsep - konsep fisika dan menyadari banyak hal atau kejadian yang dapat mereka jumpai dalam kehidupan sehari - hari yang berkaitan dengan konsep fisika yang mereka pelajari.

Kondisi dalam proses pembelajaran yang terjadi sebelum diterapkannya model pembelajaran Problem Based Learning dan model pembelajaran Discovery Learning didalam kelas eksperimen A dan kelas eksperimen B adalah sama, dimana pembelajarannya hanya berpusat pada guru sehingga siswa menajdi pasif dan tidak memiliki minat untuk belajar fisika. Setelah diterapkannya model pembelajaran Problem Based Learning dan model pembelajaran Discovery Learning maka terjadilah perbedaan tes hasil belajar terutama pada kelas eksperimen.

Perbedaan antara kedua model pembelajaran ini disebebakan oleh beberapa hal. Pertama, pada langkah pembelajaran yang digunakan dalam kedua model misalnya Discovery Learning dimana siswa lebih aktif dan terlibat langsung dalam proses pembelajaran yang dimana informasi dan pengetahuan mereka temukan secara mandiri dalam kelompok, saling berinteraksi bukan hanya dengan guru tetapi juga dengan teman mereka, sehingga kemampuan penemuan siswa secara individu maupun kelompok meningkat.
Alasan kedua yaitu, pada model pembelajaran Problem Based Learning menggunakan permasalahan sebagai poin utamanya, sebagaimana yang telah dikemukakan [8] mengenai karekteristik pembelajaran berbasis masalah bahwa permasalahan menjadi starting point dalam belajar dan permasalahan yang diangkat merupakan permasalahan yang ada di dunia nyata.

Kelebihan menggunakan kedua model pembelajaran ini membantu siswa dapat meningkatkan motivasi belajarnya karena pada pembelajaran ini mereka dilibatkan secara aktif dalam proses pembelajaran. Selain itu, model ini juga menantang kemampuan siswa, membuat siswa dapat belajar kepada teman lainnya, meningkatkan hubungan sosial yang baik, membimbing siswa dalam menanggapi pendapat temannya serta membimbing mereka bagaimna membuat hipotesis sementara dalam permasalahan yang diberikan.

Pada dasarnya kelompok kecil tersebut terdiri dari siswa yang memiliki pengetahuan dan pengalaman yang berbeda sehingga menghasilkan berbagai pendapat yang pada akhirnya menghasilkan diskusi dan membentuk kesimpulan dalam kelompok itu sendiri

\section{KESIMPULAN DAN SARAN}

Berdasarkan hasil penelitian disimpulkan bahwa terdapat perbedaan Hasil Belajar fisika antara Model pembelajaran Problem Based Learning dengan Model Pembelajaran Discovery Learning pada materi tekanan di kelas VIII SMP Negeri 12 Sigi. Hal ini ditandai oleh hasil pengujian hipotesis dengan menggunakan uji $t$ pada tes akhir memberikan nilai thitung yang lebih besar dari tabel yaitu thitung $=3,65>$ ttabel 2,01 pada taraf nyata 0,05 . Kriteria penerimaan $\mathrm{H}_{0}$ adalah jika -t $(1-0,5$ a) $<\mathrm{t}<\mathrm{t}(1-0,5$ a). Berdasarkan daftar tabel distribusi $t$ diperoleh harga $t_{\text {tabel }}=2,01$ sedangkan thitung $=3,65$. Hasil uji hipotesis ini memperlihatkan bahwa harga thitung tidak berada di dalam daerah penerimaan $\mathrm{H}_{0}$ atau dengan kata lain $\mathrm{H}_{1}$ diterima pada taraf nyatanya $a=0,05$

Pada penelitian ini pembelajaran dengan menggunakan model pembelajaran Problem Based Learning dan Model Pembelajaran Discovery Learning hanya terbatas pada materi tekanan, alangkah baiknya jika ada penelitian lanjutan dengan menggunakan model yang sama pada pokok bahasan lainnya, untuk mendapatkan masukan yang lebih lengkap agar 
perbedaan Hasil Belajar fisika antara Model pembelajaran Problem Based Learning dengan Model Pembelajaran Discovery Learning dapat diterapkan sebagai salah satu alternatif dalam pembelajaran fisika.

\section{DAFTAR PUSTAKA}

[1] Alim. (2013). "Hasil Belajar Matematika siswa kelas IV dengan Metode Problem Based Learning". IImiah Pendidikan, Sejarah dan Sosial Budaya. 15, (2), $28-40$

[2] Agnes Sri Dyah (2010). Upaya Meningkatkan Hasil Belajar Fisika melalui pendekatan Discovery Learning dengan Kegiatan Laboratorium di kelas VII SMP Negeri Cilacap. (online). Tersedia : http://www.google.com[29 oktober 2014].

[3] Arikunto, S. (1991). Prosedur Penelitian Suatu Pendekatan Praktik. Jakarta: PT. Rineka Cipta.

[4] Azwar, S. (2007). Metode Penelitian. Yogyakarta : Pustaka Belajar

[5] Maimunah. (2013). Meningkatkan Hasil Belajar Siswa pada Pembelajaran IPA dengan menggunakan Metode Discovery di SDN 16 Taruko Lintan Bou. Pedagogi Jurnal Ilmiah IImu Pendidikan Universitas Negeri Malang. 8, (1), 86-90

[6] Muhson, A. (2009). "Peningkatan Minat Belajar dan Pemahaman Mahasiswa melalui Penerapan Problem Based Learning". Jurnal Kependidikan. $39,(2), 178-182$.

[7] Nurchayati, L. (2009). Pengaruh Penggunaan Model Pembelajaran Discovery Learning Terhadap Hasil Belajar Fisika Materi Pokok Zat dan Wujudnya Kelas VII di MTS N Pamotan Rembang. (online) Tersedia : http://library.walisongo.ac.id/digilib/files/disk1/ 98/jtptiain-gdl-lilisnurch-4856-1-skripsi_9.pdf.[04, Desember 20013]

[8] Rusman. (2011). Model - Model Pembelajaran Mengembangkan Profesionalisme Guru. Jakarta: Rajawali Pers.

[9] Saputri, L. (2012). Pengaruh Penggunaan Metode Discovery pada Pelajaran IPA Pokok Bahasan Bunyi Terhadap Hasil Belajar Siswa Kelas IV SD Kristen Satya Wacana Salatiga Semester II Tahun Ajaran 2011/2012. (online) Tersedia:http://repository.library.uksw.edu/bits tream/handle/123456789/888/T1_29200140_B AB\%20IV.pdf?sequence $=5 . \quad[03$, Desember 2013]

[10] Suci, M. (2008). "Penerapan Model Problem Based Learning untuk Meningkatkan Partisipasi Belajar dan Hasil Belajar Teori Akutansi Mahasiswa Jurusan Ekonomi Undiksha". Jurnal Penelitian dan Pengembangan Pendidikan. 2, (1), 74-86

[11] Sudarman. (2007). "Problem Based Learning : Suatu Model Pembelajaran untuk mengembangkan dan meningkatkan kemampuan memecahkan masalah" Jurnal Pendidikan Inovatif. 2, (2), 6873

[12] Sudjana. (2002). Metode Statistika. Bandung: Tarsito

[13] Sudjana. (2007). Penelitian Hasil Belajar Mengajar. Bandung : PT. Remaja RosdaKarya

[14] Slameto S, (2010). Dasar - Dasar Proses Belajar Mengajar, Bandung : Sinar Baru Algesindo

[15] Sugiyono. (2011). Metodologi Penelitian Pendidikan ( Pendekatan Kuantitatif, Kualitatif dan $R \& D)$. Bandung : Alfabeta

[16] Tiona, dkk. (2009). " Indikator - Indikator Penilaian Pelaksanaan Problem- Based Learning Berdasarkan Pembeljaran Konstruktif, Mandiri, Kolaboratif, dan Kontekstual di Fakultas Kedokteran Universitas Gajah Mada". Jurnal Pendidikan Kedokteran dan Profesi Keseharan Indonesia. 4,(1),46 